\title{
How Can The Information System Be Successful In Its Implementation?
}

\author{
Sri Dewi Anggadini \\ Indonesia Computer University \\ Bandung, West Java, Indonesia
}

\begin{abstract}
This research was conducted at the Large Pharmacy Company (PBF) in Bandung Indonesia. The phenomenon is there is the heterogeneity of procedures and deviations process which occur due to non-integrated information systems. The method used in this research is descriptive method that is used to describe each of the studied variables. Verification with path analysis is used to determine the influence of user's ethics and user's competence on the quality of AIS and its effect on the quality of accounting information. The results showed that user's ethics and user's competence have significant influences on the quality of AIS, and the quality of information systems has implications on the quality of accounting information.
\end{abstract}

Keywords: user's ethics, user's competence, the quality of AIS and the quality of accounting information

\section{INTRODUCTION}

Information is a business resources organization which is needed as an effort to maintain viability (Hall, 2011: 4) and in order to survive from its competitors (Hollander et al., 2000: 9). This is because with the information, can find out how the development of operations that occur in the company and avoid the risk of doing something that is not supposed to be fatal for the organization (Azhar Susanto, 2008: 36). The quality of AI is the accounting information which need for user (Kieso et al., 2012: 3), in addition to the information have quality is needed in running an organization business (O'Brien \& Marakas, 2011: 424).

The phenomenon of accounting information in Indonesia do not meet the quality characteristics of accounting information, as presented by Indra Bastian (2006: 131) that public sector organizations in Indonesia have not had good accounting information, been often unreliable and not been audited, a disclaimer opinion on the financial statements of the ministry (Agus Martowardojo, 2012) one of which is the ministry of education and culture there are 12 findings that the conditions are certainly need improvement in AIS of each agency in the government (Herry Purnomo, 2010) and strengthen the synergy of AIS (Hadi Purnomo, 2012) because it can achieve organizational goals (Gelinas et al. ,2012: 18) and user gains quality of information for more accurate decision-making, more precise resource allocation and better response time, thus it can reduce the cost and raises profit (Laudon \& Laudon, 2014: 44). Quality of information is processed through information systems (Bodnar \& Hopwood, 2014: 6).

The phenomenon of IS on Badan Usaha Milik Negara (BUMN). Mustafa Abubakar (2010) stated there was an error in the application of information systems that the system which is integrated in new PT Garuda Indonesia can be jammed and caused dozens of chaos flight schedule. Budi Firman (2013) disclosed the amount of information systems in the working environment of PTPN VII is not yet fully integrated, that currently existing information systems in a new environment PTPN VII are limited to a few parts in the head office and 
business units. Similar conditions are also experienced by pharmaceutical companies, which the heterogeneity of procedures and irregularities process occurs (CPC 2008) as a result of a non-integrated information system (CPC 2008).

Quality of AIS depends on its user's ethics. Ethics according to Laudon \& Laudon (2014: 155) is the principles regard to truth and fraud that can be used in individual, act as free moral agents, in making choices to guide their behaviour. Ethical conditions which is deviate that happened in BUMN is submitted by Achsanul Qosasi (2015), that BPK considers regarding the establishment of BUMN subsidiaries, tends to be the place for transactions which are used for specific purposes.

The continuity of information systems could not be separated from user who performs the functions of the organization in this case, IS (Bodnar \& Hopwood, 2014: 17). As a user, an accountant should be involved in designing the AIS (Gelinas et al., 2012: 27) so that it is needed user's competence in the implementation of IS (Kassboll \& Chawani, 2010) because user's competence is one of the factors of successful IS. Competence by Spencer \& Spencer (1993: 9) is a basic characteristic of individuals which has causal relation with the referenced effective criteria for measuring the performance of a superior position or situation that is supported by the motives, talents, self-image and the orientation to always improve the performance quality. The phenomenon that occur related to the user's competence is the BUMN weakness that is triggered by internal factors one of which is the weakness of human resources capacity, lack of competence (knowledge, skills, attitudes) among employees (Megananda Daryono, 2015). Based on the phenomenon and previous studies, this research will focus on the object of study, namely: " How Can The Information System Be Successful In Its Implementation?".

\section{LITERATURE REVIEW}

McShane \& Glinow (2010: 53) argues that there are three (3) basic ethical principles, namely: Utilitarianism is a moral principle which states that in making decisions on the various alternatives should be the most beneficial to the people; Individual rights is moral principle which states that everyone is entitled to the rights and legal respectively; distributive justice is moral principle which states that everyone should be rewarded based on their respective portions.

According to Dessler (2011: 169), McShane \& Glinow (2010: 53), Mondy (2010: 244), Spencer \& Spencer (1993: 9) and McLeod \& Schell (2007: 79) that the dimensions of competence consists of : knowledge that information of someone in the area which contains specific things. Knowledge is a complex competency, it is a factor to predict the best that one can do something, it is not what to do by someone; and skillis the ability to conduct a specific task, both physically and mentally.

The quality of IS is the key for an organization to achieve success effectively (Rocheleau, 2006: 33). Furthermore, Heidmann (2008: 87) measures system quality seen from integration, flexibility, accessibility, formalization and media richness. Then, the quality of AIS is an IS capability in providing quality of accounting information which is suitable with user's needs and useful in decision making, by using the characteristics of integration, flexibility and reliability (Stair \& Reynolds, 2010: 57; Horan \& Abhichandani, 2006).

O'Brien \& Marakas statement (2011: 424), concurred with Bocij et al. (2008: 13) that attributes of information quality is a group of characteristics by which information quality can be assessed, it is usually grouped into the category of time, content and form. Quality of 
information is very useful in improving the decisions that will be taken and directly contributed to the condition in organization (Baltzan, 2014: 219). O'Brien \& Marakas (2011: 427 ) divide to three dimensional of the information quality,they are the dimension of time information (time dimension), the dimension of content information (content dimension) and the dimensions of form information (form dimension). The information which is inaccurate, obsolete (outdated) or difficult to understand will not give meaningful meaning, useless and has no value to users (O'Brien \& Marakas, 2011: 390). Then, according to McLeod \& Schell (2007: 65) say that information quality must have the characteristics of accuracy, relevancy, timeliness and complete.

\section{THEORETICAL FRAMEWORK}

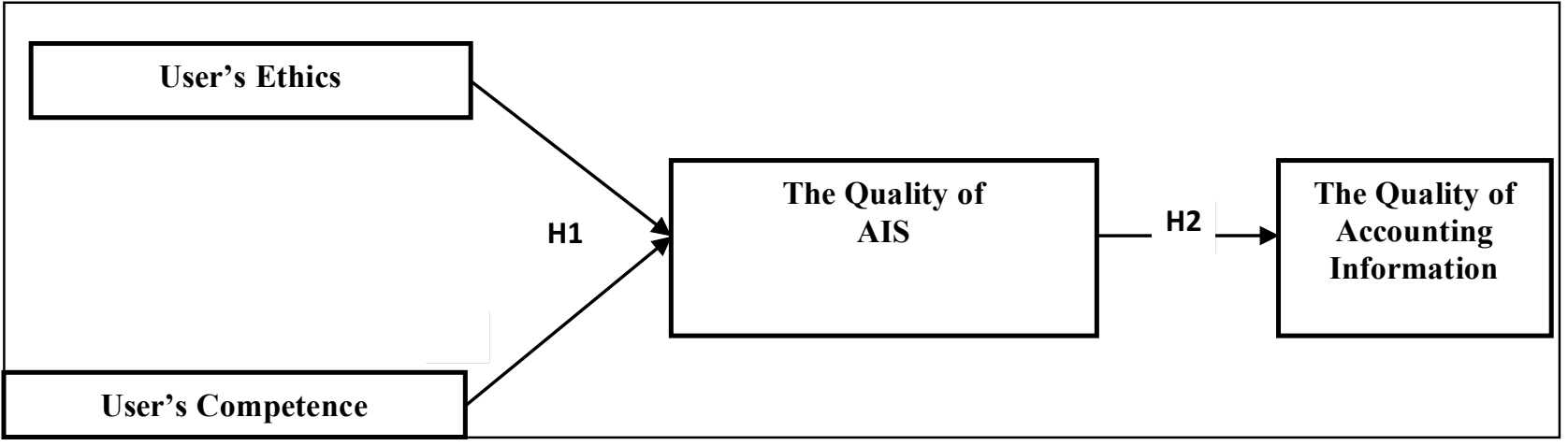

Figure 1: The Framework

Piccoli (2008: 450) states that ethics affects on IS, it means that when IS is applied, ethics as a guide for the user's behaviour based on the rules applied. Laudon \& Laudon (2014: 152) argue that one must understand how to ethics correctly which is required in the use of IS. The study results of Myers \& Venable (2014) concluded that there are 6 (six) ethical principles.

Such as that delivered by Schwalbe (2006: 14) states that the user'scompetence is the support in the implementation of IS. Likewise according to Laudon \& Laudon (2014: 136) that IS can improve the overall performance of the business unit's activity that depends on user's competence. A similar thing was expressed by Bagranoff et al. (2010: 333) that independence, competence, and best practices for audit and consulting impact on IS. Kassboll \& Chawani (2010) in their research revealed that user's competency is needed in applying IS, the competencies which is referred in the study is the knowledge possessed by the user.

AIS generates accounting information (Laudon \& Laudon, 2014: 46). Gelinas et al. (2012: 17) argues that in order to generate useful information for the organization management, it needs accounting information system that is crucial to the success of an organization. Wongsim \& Jing Gao (2011) state that AIS influences on information quality that is then used in making a decision, characterized by the dimensions of information quality.

\section{METHODOLOGY}

This study is included in the overtime study group (cross-sectional studies). Because the study is cross-sectional studies / research study which is conducted by only once collecting data, could be daily, weekly, or monthly, in order to answer the research statement (Sekaran \& Bougie, 2013: 106).

In summary, the study variables and variables operationalization in this study are as follows: 
Table 1. Variable Operationalization

\begin{tabular}{|c|c|c|c|c|}
\hline VARIABLES & DIMENSIONS & \begin{tabular}{|l} 
INDICATORS \\
\end{tabular} & SCALES & ITEMS \\
\hline \multirow[t]{3}{*}{$\begin{array}{l}\text { User's Ethics } \\
\qquad\left(\mathrm{X}_{1}\right)\end{array}$} & Utilitarianism & $\begin{array}{l}\text { 1. Giving priority to the common } \\
\text { interest } \\
\text { 2. Decision-making for the } \\
\text { usefulness of many parties }\end{array}$ & $\begin{array}{l}\text { Ordinal } \\
\text { Ordinal }\end{array}$ & $\begin{array}{l}1 \\
2\end{array}$ \\
\hline & Individual Rights & $\begin{array}{l}\text { 1. Mutual respect in interactions } \\
\text { 2. Carrying out duties based on } \\
\text { laws and rules }\end{array}$ & $\begin{array}{l}\text { Ordinal } \\
\text { Ordinal }\end{array}$ & $\begin{array}{l}3 \\
4\end{array}$ \\
\hline & Distributive Justice & $\begin{array}{l}\text { 1. The awards which is received is } \\
\text { based on the load of hand task } \\
2 \text {. Building harmony in the } \\
\text { working group }\end{array}$ & $\begin{array}{l}\text { Ordinal } \\
\text { Ordinal }\end{array}$ & $\begin{array}{l}5 \\
6\end{array}$ \\
\hline \multirow{2}{*}{$\begin{array}{l}\text { User's } \\
\text { Competence } \\
\left(\mathrm{X}_{2}\right)\end{array}$} & Knowledge & $\begin{array}{l}\text { 1. Formal education } \\
\text { 2. Working experience }\end{array}$ & $\begin{array}{l}\text { Ordinal } \\
\text { Ordinal }\end{array}$ & $\begin{array}{l}7 \\
8\end{array}$ \\
\hline & Skills & $\begin{array}{l}\text { 1. Training } \\
\text { 2. Having the ability to understand } \\
\text { the learning process }\end{array}$ & $\begin{array}{l}\text { Ordinal } \\
\text { Ordinal }\end{array}$ & $\begin{array}{c}9 \\
10\end{array}$ \\
\hline \multirow[t]{3}{*}{$\begin{array}{l}\text { The Quality of } \\
\text { AIS } \\
\text { (Y) }\end{array}$} & Integration & $\begin{array}{l}\text { 1. The integration between } \\
\text { components } \\
\text { 2. The integration between } \\
\text { transaction processing system }\end{array}$ & $\begin{array}{l}\text { Ordinal } \\
\text { Ordinal }\end{array}$ & $\begin{array}{l}11 \\
12\end{array}$ \\
\hline & Flexibilty & $\begin{array}{l}\text { 1. Able to customize the user's } \\
\text { needs } \\
\text { 2. Able to adapt to environmental } \\
\text { changes }\end{array}$ & $\begin{array}{l}\text { Ordinal } \\
\text { Ordinal }\end{array}$ & $\begin{array}{l}13 \\
14\end{array}$ \\
\hline & Reliability & $\begin{array}{l}\text { 1. Can be relied upon by users } \\
\text { 2. Error-free }\end{array}$ & $\begin{array}{l}\text { Ordinal } \\
\text { Ordinal } \\
\end{array}$ & $\begin{array}{l}15 \\
16 \\
\end{array}$ \\
\hline \multirow[t]{4}{*}{$\begin{array}{l}\text { The Quality of } \\
\text { Accounting } \\
\text { Information } \\
\text { (Z) }\end{array}$} & Accurate & $\begin{array}{l}\text { 1. Reflects the actual situation and } \\
\text { condition } \\
\text { 2. Free of bias }\end{array}$ & $\begin{array}{l}\text { Ordinal } \\
\text { Ordinal }\end{array}$ & $\begin{array}{l}17 \\
18\end{array}$ \\
\hline & Relevant & $\begin{array}{l}\text { 1. According to the needs } \\
\text { 2. Reduce uncertainty }\end{array}$ & $\begin{array}{l}\text { Ordinal } \\
\text { Ordinal }\end{array}$ & $\begin{array}{l}19 \\
20\end{array}$ \\
\hline & Timeliness & $\begin{array}{l}\text { 1. Information is available when it } \\
\text { is needed } \\
\text { 2. Information given is up to date }\end{array}$ & $\begin{array}{l}\text { Ordinal } \\
\text { Ordinal }\end{array}$ & $\begin{array}{l}21 \\
22\end{array}$ \\
\hline & Complete & $\begin{array}{l}\text { 1. Detailed Information } \\
\text { 2. Complete to support decision }\end{array}$ & $\begin{array}{l}\text { Ordinal } \\
\text { Ordinal }\end{array}$ & $\begin{array}{l}23 \\
24\end{array}$ \\
\hline
\end{tabular}

\section{Result of Measurenment}

\section{RESULT}

Table 2. The Validity and Reliability

\begin{tabular}{|l|c|c|}
\hline \multicolumn{1}{|c|}{ Variable } & Range $\mathbf{r}_{\mathbf{s}}$ & Reliability \\
\hline User's Ethics & $0.485-0.661$ & 0.7169 \\
\hline User's Competence & $0.421-0.673$ & 0.7443 \\
\hline $\begin{array}{l}\text { Quality of Accounting Information } \\
\text { System }\end{array}$ & $0.613-0.738$ & 0.7298 \\
\hline Quality of Accounting Information & $0.584-0.771$ & 0.7811 \\
\hline
\end{tabular}

The answers are treated as data and processed by statistical measures. The sincerity of the respondents' answers is crucial; therefore, the data were tested through a test of validity and reliability. 


\section{Result of Analysis}

Table 3. Descriptive Analysis of Dimensions and Variables

\begin{tabular}{|c|l|c|c|}
\hline Variables & \multicolumn{1}{|c|}{ Dimension } & Percentage & Category \\
\hline \multirow{4}{*}{ User's Ethics } & Utilitarianism & 64,7 & Fair \\
\cline { 2 - 4 } & Individual Rights & 64,9 & Fair \\
\cline { 2 - 4 } & Distributive Justice & 64,6 & Fair \\
\cline { 2 - 4 } & Average variable & $\mathbf{6 4 , 7}$ & Fair \\
\hline \multirow{4}{*}{ User's Competence } & Knowledge & 65,8 & Fair \\
\cline { 2 - 4 } & Skills & 63,9 & Fair \\
\cline { 2 - 4 } & Average variable & $\mathbf{6 4 , 9}$ & Fair \\
\hline \multirow{4}{*}{ Quality of AIS } & Integration & 50,6 & Bad \\
\cline { 2 - 4 } & Flexibility & 60,4 & Fair \\
\cline { 2 - 4 } & Reliability & 62,5 & Fair \\
\cline { 2 - 4 } & Average variable & $\mathbf{5 7 , 8}$ & Fair \\
\hline \multirow{4}{*}{ Quality of Accounting } & Accuracy & 50,4 & Bad \\
\cline { 2 - 4 } & Relevant & 64,1 & Fair \\
\cline { 2 - 4 } & Timelines & 65,2 & Bad \\
\cline { 2 - 4 } & Completeness & 63,8 & Fair \\
\cline { 2 - 4 } & Average variable & $\mathbf{6 0 , 9}$ & \\
\hline
\end{tabular}

\section{The Factor's of AIS}

As mentioned in the two-sub-structures analysis, the result of path-model research usually used to determine the magnitude of the direct or indirect influence of one variable on another variable, may be explained by Figure 2 .

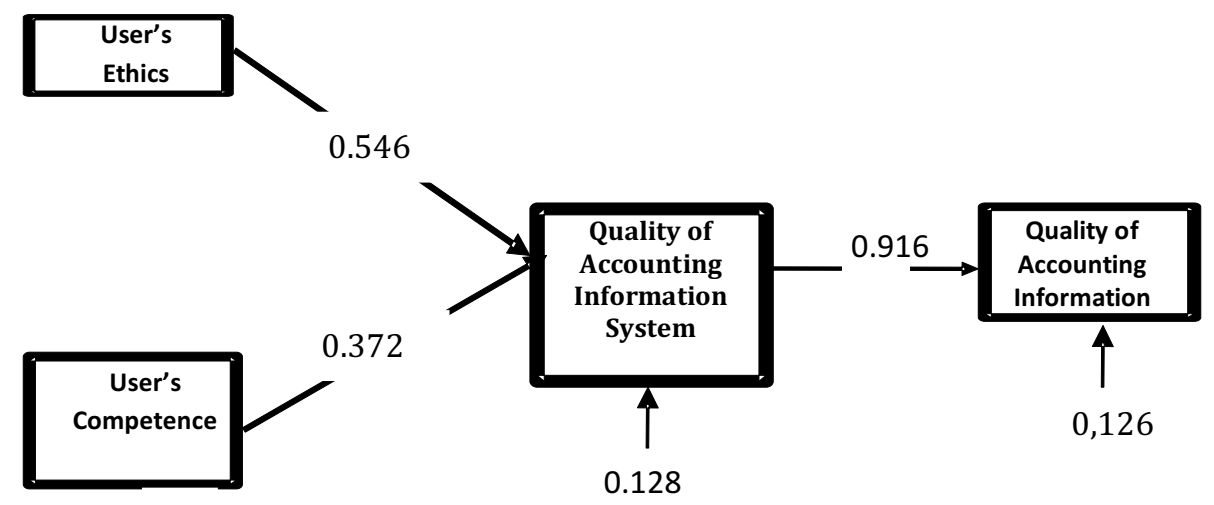

Figure 2: The Result of Research Model Path Diagram

From Figure 2, it can be concluded that:

1. The user's ethics has significant influence to the quality of AIS with the amount of influence of $45.8 \%$.

2. The user's competence have significant effect on the quality of AIS with the amount of influence of $38.7 \%$.

3. The user's ethics and the user's competence simultaneously have significant influence to the quality of AIS with the amount of influence of $87.2 \%$.

4. The quality of AIS has significant influence to the quality of accounting information with the amount of influence of $87.4 \%$.

5. The user's ethics gives influences to the quality of AIS and provides significant impact to the quality of AI with the amount of influence of $0.546 \times 0.916 \times 100 \%=50.01 \%$.

6. The user's competence give influences to the quality of AIS and provides significant impact to the quality of accounting information with the amount of influence of $0.372 \mathrm{x}$ $0.916 \times 100 \%=34.08 \%$. 
In conclusion, the results of the study supports the hypothesis suggested. First, the user's ethics and the user's competence give influences to the quality of AIS. Finally, the quality of AIS gives influence to the quality of accounting information. It means that, to reach quality of accounting information, Large Pharmacy Company (PBF) must be supported by qualified AIS. Frankly, the results of the study have significant values to the industry and support the studies conducted by Myers \& Venable (2014), Daoud \& Triki (2013) and Wongsim \& Jing Gao (2011).

\section{CONCLUSION}

The user's ethics and the user's competence implemented in Large Pharmacy Company (PBF) have significant influences on the quality of AIS both partially and simultaneously. In partial, the influences the user's ethics variable on the quality of AIS are more dominant than those of the user's competence. Otherwise, in simultaneous, the quality AIS may be achieved if the optimalization of the user's ethics and the user's competence is significantly executed.

\section{Reference}

Achsanul Qosasi. 2015. BPK Permasalahan BUMN Beralih ke Anak Perusahaan. Melalui http://www.bpk.go.id/news/bpk-permasalahan-bumn-beralih-ke-anak-perusahaan. 17 Januari 2015.

Agus Martowardojo. 2012. Menkeu Berikan Pendampingan Terhadap Disclaimer Opinion. Melalui http://www.tribunnews.com/bisnis/2012/09/11/menkeu-berikan-pendampingan-terhadap-disclaimer-opinion. 11 September 2012.

Azhar Susanto. 2008. Sistem Informasi Akuntansi, Struktur-Pengendalian-Resiko-Pengembangan. Bandung : Lingga Jaya.

Bagranoff, Nancy A., Simkin, Mark G. \& Norman, Carolyn S. 2010. Accounting Information System. USA : John Wiley \& Sons.

Baltzan, Paige. 2014. Business Driven Information Systems. $4^{\text {th }}$ Edition. USA : McGraw-Hill.

Bocij, Paul, Grasley, Andrew \& Simon Hickie. 2008. Business Information System : Technology, Development \& Management. Fourth Edition. USA : Prentice Hall.

Bodnar, George H \& Hopwood, William S. 2014. Accounting Information System. New Jersey : Prentice Hall.

Budi Firman. 2013. Bagian TI Buat Sistem Informasi Terintegrasi. Melalui http://www.bumn.go.id/ptpn7/berita/48/Bagian.TI.Buat.Sistem.Informasi.Terintegrasi. 10 April 2013.

Daoud, Hazar \& Triki, Mohamed. 2013. Accounting Information Systems in an ERP Environment and Tunisian Firm Performance. The International Journal of Digital Accounting Research. 2013. Pp. 1 - 35.

DeLone, W. H \& McLean, E. R. 1992. Information System Success : The Quest of The Dependent Variable. Information Systems Research. Vol. 3. Pp. 60-95.

Dessler, Gary. 2011. Human Resources Management. Twelfth Edition. USA : Prentice Hall.

Gelinas, JR, Ulric J, Dull, Richard B \& Wheeler, Patrick R. 2012. Accounting Information System. 9th Edition. USA : South Western Cengage Learning.

Hadi Poernomo. 2012. BPK Minta Menteri Dahlan Rapikan Aset BUMN. Melalui http://www.tempo.co/read/news/2012/06/19/087411507/BPK-Minta-Menteri-Dahlan-Rapikan-Aset-BUMN. 19 Juni 2012.

Hall, James A. 2011. Accounting Information System. $7^{\text {th }}$ Edition. USA : South-Western Publishing Co.

Heidmann, Marcus. 2008. The Role of Management Accounting Systems in Strategic Sensemaking. Germany : Respect Copyright Encourage Creativity.

Herry Purnomo. 2010. Kemenkeu 'Ikat' Instansi Pemerintah Perbaiki Laporan Keuangan. Melalui http://finance.detik.com/read/2010/07/24/105114/1405713/4/kemenkeu-ikat-instansi-pemerintah-perbaikilaporan-keuangan, 24 Juli 2010.

Hollander, Anita S., Denna, Eric L. \& Cherrington, J. Owen. 2000. Accounting, Information Technology, and Business Solutions. Second Edition. Singapore : Irwin McGraw-Hill. 
Horan, Thomas A \& Abhichandani, Tarun. 2006. Evaluating User Satisfaction in an E-Government Initiative : Resulte of Structural Equation Modeling and Focus Group Discussions. Journal of Information Technology Management. Pp. 187-198.

Indra Bastian. 2006. Akuntansi Sektor Publik Suatu Pengantar. Jakarta : Penerbit Erlangga.

Kassboll, Jens \& Chawani, Marlen Stacey. 2010. Competencies and Learning for Management Information Systems. Journal of Information, Information Technology, and Organizations. Vol. 5.Pp. 85-90.

Kieso, Donald E. Weygandt, Jerry \& Warfield, Terry D. 2012. Intermediate Accounting. 14th Edition. UK: John Willey and Sons, Inc.

Laudon, Kenneth C \& . Laudon, Jane P. 2014. Management Information Systems Managing The Digital Firm. Thirteenth Edition. America : Pearson Prentice Hall.

Megananda Daryono. 2015. Daya Saing BUMN Perkebunan Masih Lemah. Melalui http://www.beritasatu.com/ekonomi/248377-daya-saing-bumn-perkebunan-masih-lemah.html. 11 Februari $\underline{2015}$.

Mc. Leod, Raymond \& Schell, George P. 2007. Management Information System. Tenth Edition. Upper Saddle River New Jersey 07458 : Pearson / Prentice Hall.

McShane \& Glinow, Von. 2010. Organizational Behaviour. Fifth Edition. Singapore : McGraw-Hill International Edition.

Mondy, R. Wayne. 2010. Human Resources Management. Eleventh Edition. 2010. USA : Prentice Hall. New Jersey.

Mustafa Abubakar. 2010. Menteri BUMN Bingung Sistem Baru Garuda Malah Bikin Kacau. Melalui http://finance.detik.com/read/2010/11/24/155406/1501460/4/menteri-bumn-bingung-sistem-baru-garudamalah-bikin-kacau. 24 Nopember 2010.

Myers, Michael D \& Venable, John R. 2014. A Set of Ethical Principles for Design Science Research in Information Systems. Information \& Management. 51. Pp. 801-809.

O’Brien , James A. \& Marakas, George M. 2011. Management Information Systems. Tenth Edition. New York: McGraw-Hill Irwin.

Piccoli, Gabriele. 2008. Information Systems for Managers. Text and Cases. USA : John Wiley \& Sons Inc. United States of America.

Rocheleau, Bruce. 2006. Public Management Information System. 2006. All rights Reserved.

Schwalbe, Kathy. 2006. Introduction to Project Management. Course Technology Thomson Learning. Inc. USA : Cengage Learning, Inc. Boston, Massachussetts.

Sekaran, Uma \& Bougie, Roger. 2013. Research Methods for Business. Sixth Edition. United Kingdom : John Wiley \& Sons Ltd.

Spencer, Lyle M., JR. \& Spencer, Signe M. 1993. Competence Work, Models for Superior Performance. Canada : Jhon Willey \& Sons.

Stair, Ralph M \& Reynolds, George W. 2010. Principles of Information Systems, Course Technology. 9th Editions. New York : Mc-Graw-Hill

Wongsim, M., \& Jing Gao. 2011. Exploring Information Quality in Accounting Information System Adoption. IBIMA Publishing. Pp. 1-12. 